\title{
Two cases of male breast cancer at a university hospital in southeast Brazil
}

This article was published in the following Dove Press journal:

International Journal of General Medicine

15 June 2013

Number of times this article has been viewed

Fabiana Resende Rodrigues'

André Vallejo da Silva ${ }^{2}$

Calina Maria Loures de

Oliveira Teixeira ${ }^{2}$

Samantha Cunha Gomes

Antunes ${ }^{2}$

Mayra Carrijo Rochael'

'Pathology Service, Pathology Department, ${ }^{2}$ Breast Service,

Maternal and Infant Department, Hospital Universitário Antonio Pedro,

Universidade Federal Fluminense,

Niterói, Rio de Janeiro, Brazil
Correspondence: Fabiana Resende Rodrigues

Hospital Universitário Antonio

Pedro, Rua Marques de Paraná 303,

Departamento de Patologia, 4o Andar

Centro, Niterói, Rio de Janeiro,

RJ 24033-900, Brasil

Tel +55 2l 26299033

Email resendefr@yahoo.com.br

\begin{abstract}
We report two rare cases of breast cancer in men treated with modified radical mastectomy. The patients were aged 67 and 45 years at the time of diagnosis. Tumor sizes were $2 \mathrm{~cm}$ and $8 \mathrm{~cm}$ in the older and younger patient, respectively. The histopathologic diagnosis was infiltrating ductal carcinoma in the first patient and infiltrating papillary carcinoma in the second patient. Immunohistochemical tests demonstrated estrogen and progesterone receptor positivity and HER2/c-erbB-2 negativity in both cases. The rarity of these cases is noted, in view of their uncommon occurrence at an early age in men and their immunophenotypic positivity, similar to breast cancer in women.
\end{abstract}

Keywords: breast cancer, men, histopathology, immunohistochemistry, radical mastectomy

\section{Introduction}

Breast cancer is the second most frequent type of cancer worldwide (accounting for $15 \%$ of all cancers), after lung cancer ( $25 \%-50 \%)$, excluding squamous and basal cell carcinomas of the skin. ${ }^{1}$ Each year, the worldwide incidence of new cases of breast cancer in women is about $31 \%$, while in men the incidence is much lower (about $1 \%$ ). Therefore, the diagnosis of breast cancer in men is often delayed until it presents at an advanced stage. The incidence is highest between the age of 65 and 67 years, which is approximately 10 years later than female breast cancer. ${ }^{2}$ Studies show that the risk for development of male breast cancer may be increased due to relatively high estrogen levels compared with androgens (exogenous administration of estrogens, Klinefelter's syndrome, cirrhosis of the liver, chronic hepatosplenic schistosomiasis), obesity, use of marijuana, previous bilateral orchitis, exposure to chronic high temperatures, and treatment of prostate cancer. ${ }^{3}$

\section{Case reports}

We report two cases of breast cancer in men, with reference to clinical data, histopathologic correlation, and immunohistochemistry. Both patients were black and underwent a radical Patey mastectomy, with the tumor being detected in the retroareolar region in both cases. The first patient was 67 years old and his main complaint was of a tumor mass in the right breast with ulcerated overlying skin. On physical examination, the tumor was a firm $8.0 \times 5.5 \mathrm{~cm}$ mass, with palpable axillary lymph nodes. The second patient was 45 years old and had a bulging lump in the left breast. Firm axillary lymph nodes, two centimeters in diameter, were noted. Axillary lymph nodes, two centimeters in diameter were noted, and, in both cases no metastasis has been detected. The first 
patient showed in the tumor extensive areas of necrosis and perineural infiltration. Other relevant clinical data, as well as histopathologic and immunohistochemical studies, are shown in Table 1.

\section{Discussion}

Breast cancer is the main cause of death among women in Brazil. According to the National Cancer Institute, the national estimated risk for new cases of breast cancer in 2012 was 52 cases per 100,000 women. Although the prognosis is considered relatively good if diagnosed and treated early, death rates from breast cancer remain high in Brazil, most likely because the disease is still diagnosed in its advanced stages in our population. The median survival worldwide after five years is $61 \%$, whereas in Brazil it is $57 \%{ }^{4}$

Family history is an important risk factor for female breast cancer, increasing two to nine fold the risk of tumor, especially if one or more first-degree relative (mother or sister) has breast cancer before 50 years of age. However, a family history of breast cancer only accounts for approximately $10 \%$ of all cases of breast cancer. The presence of a family history of female breast cancer does not affect survival in men with breast cancer. Approximately $15 \%-20 \%$ of male patients with breast cancer have a positive family history for this pathology. ${ }^{5}$ Of our two cases, only the younger patient had a family history of female breast cancer. Of note is the early onset of the disease in this patient, in contrast with the literature which reports a peak in the disease at the age of 65 years in men. The rarity of the disease in men makes it difficult to establish the role of familial factors in survival. Regular intake of alcohol in both genders, even in moderate amounts, is identified as a risk factor for breast cancer, as well as exposure to ionizing radiation below the age of 35 years. ${ }^{6}$ Both patients reported regular intake of alcohol in moderate amounts.

The frequency of breast cancer in the upper lateral, central quadrant (or retroareolar), and other quadrants is $50 \%, 20 \%$, and $30 \%$, respectively. In both our patients, the tumors were detected in the retroareolar region. The main form of presentation of symptomatic breast cancer is a palpable lump or tumor, with or without pain. Both patients presented masses without pain. Other forms of presentation are thickening of the parenchyma, bulging or retraction of the skin, a texture similar to orange peel (peau d'orange), bloody discharge from the nipple, inversion of the nipple, and axillary lymphadenopathy. ${ }^{7}$

The most important prognostic factors for breast cancer in both genders are tumor stage, histologic type, hormone receptor status (estrogen and progesterone), and expression of oncogenes, such as $H E R 2 / c-e r b B-2 .{ }^{8}$ Hormone receptor expression is associated with low tumor grade. Thus, one can consider the hormonal status in breast carcinoma as the most important predictive factor for local and systemic recurrence and disease-free survival. Like the estrogen receptor, the progesterone receptor is a nuclear receptor which is encoded by genes located on chromosome 11q22-23, expressed as two proteins of similar weight, ie, RP $\alpha$ (weighing approximately $85 \mathrm{kDa}$ ) and $\mathrm{RP} \beta$ (weighing approximately $110 \mathrm{kDa}$ ). Expression of progesterone and estrogen nuclear receptors predicts for lesser rates of recurrence and improved survival rate. ${ }^{4}$ Male breast cancer has a higher rate of positivity for hormonal receptors than female breast cancer, the estrogen receptor being positive in $81 \%$ of cases as well as the progesterone receptor in $74 \%$, with positivity in female cases being $57 \%$ for both receptors. ${ }^{9}$ The cases reported here were strongly positive for hormone receptors, with a positivity range of $50 \%-100 \%$, in agreement with the literature. As in female breast cancer, hormonal therapy and adjuvant chemotherapy is indicated in most men with breast cancer, particularly when the tumor is larger than $1 \mathrm{~cm}$ or if lymph nodes are involved. ${ }^{10}$

The HER2/c-erbB-2 oncogene has been labeled variously as CERB-B2, cerbB-2, C-erbB-2, Her2, Her-2/neu, ERBB2, erbB2, erbB-2, neu/c-erbB-2 oncogene neu, neu protein, and neutral. It is a member of the epidermal growth factor receptor family, a subfamily of the type 2 tyrosine kinases. It is located on chromosome 17q21 and encodes a transmembrane glycoprotein, p185HER2, which is expressed at low levels in epithelial cells and in normal myoepithelial breast tissue. ${ }^{11}$ The location of this receptor in the cell membrane makes this molecule an ideal target for adjuvant

Table I Clinical and pathologic features of two male patients with breast cancer and immunohistochemical results

\begin{tabular}{|c|c|c|c|c|c|c|c|c|c|}
\hline Case & Age, years & Side & Type* & $\begin{array}{l}\mathrm{pT} \\
(\mathrm{cm})\end{array}$ & $\begin{array}{l}\text { Size } \\
\text { LN }>\end{array}$ & M/LN & ER & PR & $\begin{array}{l}\text { CERB-B2 } \\
\text { oncogene }\end{array}$ \\
\hline 1 & 67 & $\mathrm{R}$ & CDI & 8 & $3.5 \mathrm{~cm}$ & $0 / 39$ & $>75 \%$ & $>75 \%$ & $+1 /+3$ \\
\hline 2 & 45 & L & $\mathrm{CPI}$ & 2 & $2.0 \mathrm{~cm}$ & $0 / 12$ & $50 \%-75 \%$ & $100 \%$ & negative \\
\hline
\end{tabular}

Note: *Histologic type.

Abbreviations: p, pathologic; T, tumor; R, right; L, left; CDI, infiltrating ductal carcinoma; CPI, infiltrating papillary carcinoma; M, metastasis; LN, lymph node; ER, estrogen receptor; PR, progesterone receptor. 
or neoadjuvant therapy. Its overexpression is associated with breast tumors having aggressive biologic behavior, especially in patients with lymph node invasion, and is associated with a worse prognosis, reduced survival time, rapid tumor growth, and increased frequency of recurrence after surgery. ${ }^{12}$ Neither patient in this study demonstrated this immunophenotype and thus had a better prognosis.

The stage of disease at diagnosis may reflect not only the growth rate and extent of the tumor, but also the type of tumor and the tumor-host relationship. The axillary lymph nodes are usually the first to be invaded. The most common sites for distant metastases are lungs, liver, bone, brain, and for unknown reasons, the adrenal glands. ${ }^{13}$ Capsular nodal invasion, extranodal extension, and coalescence of lymph node metastasis as possible risk factors for recurrence of breast cancer are a matter of controversy, but should be reported. ${ }^{14}$ Jobim et al $^{15}$ studied 88 cases of mammary tumors, and reported that when the tumor measured more than $2.7 \pm 1.1 \mathrm{~cm}$ and had lymph node metastasis, vascular invasion was found in $84 \%$ of cases. These authors concluded that the positivity of lymph nodes is directly correlated with greater tumor diameter. They succeeded in isolating a high number $(n=44)$ of nodes. In our cases, we could identify both capsular invasion and nodal capsular leakage, and in case 1, lymphatic neoplastic emboli, perineural infiltration, infiltration of the skin, and tumor necrosis.

Although breast cancer is similar in males and females, notable differences have been reported, including lower histologic grade and hormone receptor positivity in men. ${ }^{16}$ When compared with female breast cancer, male breast cancer generally presents at a more advanced stage and with more metastatic lymph nodes at diagnosis. It is common for the diagnosis to be delayed in men because they are in general unaware of the fact that breast cancer is a possibility. Proximity to the skin allows for quicker invasion of lymphatic vessels and spread to regional lymph nodes as well as development of distant disease. ${ }^{17}$ Male breast cancer is considered to be biologically more aggressive than female breast cancer. ${ }^{8}$ Historically, male breast cancer has been regarded as having a worse prognosis. However, some studies have concluded that the overall survival rate of $86 \%$ and $56 \%$ for 5 and 10 years corresponds to a similar prognosis in women at the same age and stage of disease at the time of diagnosis. ${ }^{18}$

While breast-conserving therapy is preferred for female breast cancer, the small amount of breast tissue in men does not justify conservative surgical procedures. ${ }^{19}$ In both cases described here, radical mastectomy was performed.
We conclude that male breast cancer, although rare, should always be considered in the presence of a nodule or mass in this region, so that early diagnosis can be made, leading to better patient survival rates, as is the case in women.

\section{Disclosure}

The authors report no conflicts of interest in this work.

\section{References}

1. World Health Organization. World Health Statistics 2009. Available from: http://www.who.int/whosis/whostat/2009/en/index.html. Accessed May 3, 2013.

2. Giordano SH, Buzdar AU, Hortobagyi GN. Breast cancer in men. Ann Intern Med. 2002;137(8):678-687.

3. Weiss JR, Moysich KB, Swede H. Epidemiology of male breast cancer. Cancer Epidemiol Biomarkers Prev. 2005;14(1):20-26.

4. Instituto Nacionale de Cancer. [News Agency launches National Institute of Cancer, 2011. Estimate 2012: Incidence of cancer in Brazil]. Available from: http://www.inca.gov.br/estimativa/2012/. Accessed May 3, 2013. Portuguese.

5. Barnett GC, Shah M, Redman K, Easton DF, Ponder BA, Pharoah PD. Risk factors for the incidence of breast cancer: do they affect survival from the disease? J Clin Oncol. 2008;26(20):3310-3316.

6. Fentiman I. Male breast cancer: a review. Ecancermedicalscience. 2009;3(9510):140-147.

7. De los Santos JF, Buchholz TA. Carcinoma of the male breast. Curr Treat Options Oncol. 2000;1(3):221-227.

8. Onitilo AA, Engel JM, Greenlee RT, Mukesh BN. Breast cancer subtypes based on ER/PR and Her2 expression: comparison of clinicopathologic features and survival. Clin Med Res. 2009;7(1-2):4-13.

9. Lin FML, Pincerato KM, Bacchi CE, Baracat EC, Carvalho FM. Coordinated expression of estrogen and androgen receptors in HER2positive breast carcinoma: impact on proliferative activity. $J$ Clin Pathol. 2012;65(1):64-68.

10. Beck CA, Zhang Y, Weigel NL, Edwards DP. Two types of anti-progestins have distinct effects on site-specific phosphorylation of human progesterone receptor. J Biol Chem. 1996;271(2):1209-1217.

11. Giani C, Casalini P, Pupa SM, et al. Increased expression of c-erbB-2 in hormone-dependent breast cancer cells inhibits growth and induces cell differentiation. Oncogene. 1998;17(4):425-432.

12. Elmore JG, Armstrong K, Lehman CD, Fletcher SW. Screening for breast cancer. JAMA. 2005;293(10):1245-1256.

13. Kuru B, Camlibel M, Gulcelik MA, Alagol H. Prognostic factors affecting survival and disease-free survival in lymph node-negative breast carcinomas. J Surg Oncol. 2003;83(3):167-172.

14. Gómez-Raposo C, Zambrana Tévar F, Sereno Moyano M, López Gómez M, Casado E. Male breast cancer. Cancer Treat Rev. 2010;36(6): 451-457.

15. Jobim FC, Schwartsmann G, Xavier NL, Uchoa DM, Saciloto M, Chemello N. [Expression of MMP-9 and VEGF in breast cancer: correlation with other prognostic indicators.] Rev Bras Ginecol Obstet. 2008;30(6);287-293. Portuguese.

16. Marchal F, Salou M, Marchal C, Lesur A, Desandes E. Men with breast cancer have same disease-specific and event-free survival the women. Ann Surg Oncol. 2009;16(4):972-978.

17. Nahleh ZA, Srikantiah R, Safa M, Jazieh AR, Muhleman A, Komrokji R. Male breast cancer in the veterans affairs population: a comparative analysis. Cancer. 2007;109(8):1471-1477.

18. Siddiqui MT, Zakowski MF, Ashfaq R, Ali SZ. Breast masses in males: multi-institutional experience on fine-needle aspiration. Diagn Cytopathol. 2002;26(2):87-91.

19. Agrawal A, Ayantunde AA, Rampaul R, Robertson JFR. Male breast cancer: a review of clinical management. Breast Cancer Res Treat. 2007;103(1):11-21. 


\section{Publish your work in this journal}

The International Journal of General Medicine is an international, peer-reviewed open-access journal that focuses on general and internal medicine, pathogenesis, epidemiology, diagnosis, monitoring and treatment protocols. The journal is characterized by the rapid reporting of reviews, original research and clinical studies across all disease areas.

A key focus is the elucidation of disease processes and management protocols resulting in improved outcomes for the patient.The manuscript management system is completely online and includes a very quick and fair peer-review system. Visit http://www.dovepress.com/ testimonials.php to read real quotes from published authors.

Submit your manuscript here: http://www.dovepress.com/international-journal-of-general-medicine-journal 